\title{
STRATEGI MANAJEMEN KRISIS PUBLIC RELATIONS KOMISI PERLINDUNGAN ANAK INDONESIA (KPAI)
}

\author{
Kenni Cea', Rut Rismanta Silalahi' ${ }^{2}$, Ratu Nadya ${ }^{3}$ \\ ${ }^{123}$ Universitas Pembangunan Nasional Veteran Jakarta \\ Korespondensi: Jalan RS. Fatmawati Raya, Pondok Labu, \\ Kec. Cilandak, Kota Depok, Jawa Barat, 12450, Indonesia \\ Surel: kennycea@rocketmail.com
}

\section{INFO ARTIKEL}

\section{Sejarah Artikel:}

Diterima: 20/06/2020

Direvisi: 20/09/2020

Dipublikasikan: 30/09/2020

e-ISSN: 2721-0995

p-ISSN: 2721-9046

Kata Kunci:

Manajemen Krisis, Public

Relations

Keywords:

Crisis Management, Public Relations

\section{ABSTRAK}

Strategi Manajemen Krisis Public Relations Komisi Perlindungan Anak Indonesia (KPAI). Tujuan penelitian ini ingin mengetahui strategi manajemen krisis yang digunakan oleh public relations KPAI kemudian untuk mengetahui hambatan yang dihadapi oleh public relations dan seperti apa bentuk dukungan yang diterima oleh KPAI selama pelaksanaan manajemen krisis. Teori yang digunakan yaitu Teori Situasional Crisis Communication Theory (SCCT) atau teori komunikasi krisis situasional, yaitu menghubungkan antara strategi respons krisis dengan situasi krisis di mana organisasi merangkai strategi respons krisis sebagai jawaban untuk menyelamatkan reputasinya. Metode yang digunakan yaitu kualitatif dengan pendekatan studi kasus. Teknik pengumpulan data dilakukan dengan cara wawancara mendalam dan dokumentasi. Hasil penelitian adalah strategi manajemen krisis yang dilakukan oleh public relations KPAl yaitu melakukan rapat internal, melangsungkan konferensi pers serta membuat press release yang kemudian media mempublikasikannya.

\section{ABSTRACT}

Public Relations Crisis Management Strategy of the Childen Protection Commision (KPAI). The purpose of this study is to find out how the crisis management strategy used by KPAl public relations then to find out what obstacles are faced by public relations and what kind of support received by KPAI during the implementation of crisis management. The theory used is the Situational Crisis Communication Theory (SCCT) or the theory of situational crisis communication, which connects crisis response strategies with crisis situations where the organization assembles crisis response strategies in response to saving its reputation. The method used is qualitative with a case study approach. Data collection techniques are done by in-depth interviews and documentation. The result of this research is a crisis management strategy carried out by KPAl's public relations, namely conducting internal meetings, holding press conferences and making press releases which then the media publish. 


\section{PENDAHULUAN}

Berdasarkan Konvensi Hak Anak Internasional pada 1989, The United Nations Children's Fund atau biasa disingkat Unicef (2019) menyatakan bahwa setiap anak dijamin hak-haknya tanpa diskriminasi dalam bentuk apapun yang secara umum memberikan perlindungan dari kekerasan pelecehan dan eksploitasi serta penghargaan terhadap anak. Oleh karena itu, setiap anak berhak atas kelangsungan hidup, tumbuh dan berkembang serta berhak atas perlindungan dari kekerasan dan diskriminasi. Untuk memberi perlindungan hukum kepada anak, Pemerintah Indonesia membuat UU Nomor 23 Tahun 2002 tentang Perlindungan Anak yang kemudian dibentuklah Komisi Perlindungan Anak Indonesia (KPAI) setahun setelahnya. KPAl adalah lembaga negara independen yang sejajar kedudukannya dengan komisi-komisi lain seperti Komisi Penyiaran Indonesia (KPI), Komisi Nasional Hak Asasi Manusia (Komnas HAM), dan lain-lain. Berbagai kasus yang ditangani oleh KPAI berkaitan dengan pelanggaran hak anak, kekerasan pada anak, serta banyak bekerja sama dengan lembaga masyarakat di bidang perlindungan anak.

Kajian yang diterima oleh KPAI berasal dari lembaga sosial masyarakat, yaitu Yayasan Lentera Anak. Dalam kajian tersebut dinyatakan bahwa terjadi kenaikan angka merokok pada anak yang semula 7.2\% pada 2013 meningkat menjadi 8,8\% pada 2016, kemudian ditargetkan turun di angka 5,4\% pada 2018, tetapi malah meningkat menjadi 9,1\% pada 2019. Data kajian tersebut juga menyampaikan bahwa 4 dari 5 anak mengenal rokok melalui iklan. Berdasarkan data itu, dapat ditarik kesimpulan bahwa iklan rokok berdampak pada kenaikan angka merokok pada anak. Menanggapi hal ini, KPAI mengevaluasi kajian yang diterima itu sebagai implementasi fungsi pengawasan, pada awal September 2019. KPAl mengajukan keberatannya terhadap Djarum Foundation berkenaan dengan penggunaan logo dan merek dari Djarum pada atribut yang digunakan oleh peserta beasiswa Perkumpulan Bulu Tangkis Djarum (PB Djarum).

KPAI menganggap ada eksploitasi terselubung terhadap anak-anak dalam program tersebut. Berdasarkan pemberitaan pada 18 September 2019 oleh Kompas dinyatakan bahwa perihal keberatan tersebut disampaikan dalam rapat yang dihadiri oleh perwakilan dari Kementerian Koordinator Bidang Politik, Hukum, dan Keamanan (Kemenko Polhukam), Kementerian Koordinator Pembangunan Manusia dan Kebudayaan (Kemenko PMK), Kementerian Pemuda dan Olahraga (Kemenpora), Kementerian Pemberdayaan Perempuan dan Perlindungan Anak (KPPPA), Kementerian Hukum dan Hak Asasi Manusia (Kemenkumham), perwakilan Wali Kota Surabaya, Kabupaten Kudus, Kabupaten Banyumas, Komite Olahraga Nasional Indonesia (KONI), Persatuan Bulu Tangkis Seluruh Indonesia (PBSI), dan PB Djarum Foundation. Namun pihak dari PB Djarum Foundation tidak dapat menghadiri rapat tersebut dikarenakan alasan teknis.

PB Djarum Foundation mengeluarkan suatu keputusan bahwa pihaknya akan menghentikan Audisi Umum Beasiswa Djarum mulai 2020. Di sisi lain pihak KPAl sebenarnya bukan ingin mengajukan penghentian audisi bulu tangkis untuk anak-anak yang diselenggarakan PB Djarum, tetapi KPAI meminta agar dalam penyelenggaraan audisi 
tidak boleh menggunakan nama merek, logo, dan gambar produk tembakau yang diatur dalam Peraturan Pemerintah Nomor 109 tahun 2012. KPAI mendapat banyak respons baik negatif maupun positif. Tagar \#BubarkanKPAI menjadi ramai di media sosial Twitter pada 9 September 2019, banyak netizen di Twitter, Instagram dan juga terdapat petisi online yang menyerang KPAI selama beberapa hari dikarenakan KPAI dituding sebagai pihak yang membuat PB Djarum memberhentikan audisi beasiswa bulu tangkis yang sudah sejak 2006 diselenggarakan ini. Dampak lain yang dialami oleh KPAI juga antara lain, akun Instagram yang sempat di-hack mengakibatkan beberapa foto hilang. Website KPAl yang juga di-hack kemudian saat dibuka terdapat tulisan-tulisan dengan kata kasar yang menyampaikan agar KPAI sebaiknya dibubarkan. Sampai kepada anggota KPAl yang kehilangan akun Instagramnya, dan juga diancam akan dilukai. Banyaknya dampak negatif yang muncul membuat pihak KPAI merasa resah dan terancam.

Pada 12 September 2019, KPAI dan PB Djarum melakukan kesepakatan bersama di gedung Kementerian Pemuda dan Olahraga. Kedua belah pihak mencapai kesepakatan bersama dan mengakhiri polemik seputar audisi beasiswa PB Djarum. Keunikan dari krisis yang terjadi pada KPAI adalah lembaga ini memiliki maksud dan tujuan yang bertumpu pada peraturan perundang-undangan yang telah ada. KPAI hanya ingin anak-anak yang mengikuti audisi beasiswa ini tidak masuk dalam bentuk eksploitasi dan bukan untuk membubarkan penyelenggaraan beasiswa yang telah berlangsung sejak 2006 ini. Intensi KPAI bersifat baik tetapi mendapat serangan dari masyarakat.

Saat terjadi masalah krisis pada suatu organisasi, peran Public Relations menjadi hal yang sangat penting. Pada dasarnya peran dari seorang Public Relations dibutuhkan untuk memantau serta meninjau kejadian atau peristiwa yang sedang terjadi di antara berbagai pihak terkait dengan organisasi atau perusahaan. Ketika organisasi mengalami masalah, maka akan muncul dampaknya. Dampak dari masalah yang terjadi bisa berupa penurunan citra dan juga kepercayaan publik terhadap perusahan ataupun organisasi. Tim Public Relations hadir untuk menyusun strategi program komunikasi untuk penanganan suatu masalah. Hal tersebut bertujuan untuk memperbaiki hubungan dan posisi perusahan di mata masyarakat sehingga tidak menimbulkan kesalahpahaman khususnya atas permasalahan yang terjadi. Berdasarkan uraian di atas, penulis tertarik untuk meneliti strategi manajemen krisis yang dilakukan Public Relations KPAI di tengah tekanan yang dilakukan oleh masyarakat tersebut.

\section{TINJAUAN PUSTAKA}

Public Relations menurut Frank Jefkins (2003:9) adalah semua bentuk komunikasi yang terencana, baik itu ke dalam maupun ke luar, antara suatu organisasi dengan semua khalayaknya dalam rangka mencapai tujuan-tujuan spesifik yang berlandaskan pada saling pengertian. Tujuan utama dari Public Relations adalah memengaruhi perilaku orang, baik secara individu maupun kelompok saat saling berhubungan dengan harapan dapat menanamkan keinginan dan kepercayaan sehingga saling adanya pengertian dan 
citra yang baik dari publiknya (Roslan Rosady, 2012).

Manajemen Krisis merupakan langkah yang harus segera dilakukan untuk dapat menghindari kerugian yang jauh lebih besar ke depannya. Hal ini penting untuk menjaga nama baik organisasi dan perusahaan. Muray (2001) menjelaskan bahwa manajemen krisis merupakan suatu pendekatan terstruktur dalam menghadapi krisis yang terjadi. Tujuannya adalah menempatkan suatu desain strategi komunikasi, yakni informasi dapat disampaikan secara cepat dan tepat. Di samping itu juga bertujuan untuk mengurangi risiko sekecilkecilnya dengan cara memperbaiki kesalahan informasi dan membantu mengurangi kerusakan yang ditimbulkan oleh krisis. Rencana manajemen krisis dimulai dengan melakukan identifikasi dari skenario-skenario krisis yang dapat menimpa perusahaan yang kemudian dijadikan suatu rancangan mekanisme komunikasi yang berguna untuk mengatur suatu krisis secara cepat, serta membantu karyawan dalam menentukan skala prioritas masalah.

Dalam Manajemen Krisis, Public Relations memiliki tugas merencanakan strategi manajemen krisis ketika krisis terjadi. Dalam sudut pandang public relations, manajemen krisis adalah pendekatan yang terstruktur dalam penanganan suatu kejadian, dengan tujuan untuk memberikan strategi komunikasi yang tepat sehingga informasi yang diberikan sampai pada khalayak dengan cepat, meminimalkan risiko kesalahan informasi dan membantu mengurangi kerugian (Muray, 2001:43). Strategi Public Relations dalam merespons krisis perusahaan harus mempersiapkan dengan matang cara mencegah terjadinya krisis. Perusahaan sebaiknya selalu membuat rencana dalam menghadapi krisis dan menghindari keputusan yang justru akan membuat perusahaan terperosok lebih jauh dalam krisis.

\section{METODE}

Penelitian ini menggunakan pendekatan kualitatif dengan metode studi kasus. Dalam hal ini, peneliti ingin menyelidiki secara mendalam dan detail peristiwa yang terjadi di dalam suatu lembaga berkaitan dengan segala sesuatu yang berperan dalam suatu kasus, misalnya peristiwa terjadinya, proses perkembangan, dan tindakan yang diambil. Metode yang digunakan adalah metode studi kasus sesuai yang disampaikan oleh Robert K Yin (2008). Studi kasus digunakan sebagai suatu penjelasan komprehensif yang berkaitan dengan berbagai aspek seseorang, suatu kelompok, suatu organisasi, suatu program, atau suatu situasi kemasyarakatan yang diteliti, diupayakan dan ditelaah sedalam-dalamnya.

Penelitian ini dilakukan di Kantor Pusat KPAl, fokus penelitian ini adalah tentang strategi manajemen krisis Public Relations KPAl. Teknik pengumpulan data pada penelitian ini adalah dengan wawancara, dokumentasi serta didukung artikel berita dan data konten digital. Pemilihan informant dan key informant pada penelitian ini berdasarkan pada purposive sampling. Purposive sampling adalah teknik pengambilan sampel sumber data dengan pertimbangan tertentu, misalnya orang tersebut dianggap paling tahu tentang apa yang diharapkan atau mungkin dia sebagai penguasa sehingga akan memudahkan peneliti menjelajahi pengambilan sampel sumber data (Sugiyono, 2014). Public Relations 
KPAI sebagai key informant dan Kepala Sekretariat KPAI sebagai informant.

Dalam teknik analisis data dilakukan proses mengolah seluruh data yang didapat dari proses pengambilan data dengan teknik wawancara dan dokumentasi. Data-data ini terdiri atas narasi, hasil tanya jawab wawancara, rekaman, catatan, teks berita atau press release dan lain-lain. Tahapan yang dilalui penulis antara lain ialah penulis melakukan penelusuran dan mengumpulkan data yan berkaitan dengan masalah penelitian, kemudian dilanjutkan dengan melakukan penyusunan data-data yang telah didapat, di sini peneliti memilah data mana yang penting dan kurang penting. Peneliti akan memasuki tahap penyajian data, yakni mengatur data yang sudah disusun secara sistematis dan lengkap serta diakhiri dengan membuat kesimpulan serta laporan.

Pengujian keabsahan data yang dilakukan peneliti yaitu dengan triangulasi metode. Menurut Denkin (Raharjo, 2017) dijelaskan bahwa triangulasi metode dilakukan dengan cara membandingkan informasi atau data dengan cara yang berbeda. Dalam penelitian kualitatif ini, peneliti menggunakan metode wawancara, observasi, dan survei.

\section{HASIL DAN PEMBAHASAN}

Berdasarkan hasil wawancara yang didapat mengenai strategi manajemen krisis yang dilakukan oleh Komisi Perlindungan Anak Indonesia, terdapat beberapa strategi yang dilakukan antara lain melakukan rapat internal, melangsungkan press conference, dan membuat press release. Berikut ini adalah uraian masing-masing strategi:

1. Melakukan Rapat Internal

Rapat internal adalah pihak internal, baik itu staff terkait serta pimpinan lembaga berkumpul bersama untuk membahas suatu masalah atau memutuskan suatu hal yang berkaitan dengan lembaga tersebut untuk kepentingan bersama. Humas KPAI melakukan koordinasi untuk melangsungkan rapat internal tatap muka di kantor KPAI yang terletak di Menteng, Jakarta Pusat. Rapat internal dilakukan setelah keluarnya pernyataan dari pihak PB Djarum bahwa mereka memberhentikan audisi beasiswa bulu tangkis tersebut. Rapat internal memiliki tujuan untuk membahas tindakan yang selanjutnya dilakukan, dikarenakan dengan dilakukannya rapat internal, pemimpin yang terkait ikut merumuskan solusi akan masalah yang dihadapi guna meredam emosi masyarakat dan juga agar tujuan yang dimaksud tercapai.

\section{Melakukan Konferensi Pers}

Selain melakukan rapat internal, Humas KPAI juga memutuskan untuk melakukan strategi dengan cara konferensi pers. Konferensi pers merupakan sarana publikasi kepada masyarakat untuk menyampaikan pernyataan, mengumumkan atau menjelaskan suatu perihal. Konferensi pers dilakukan dengan mengundang berbagai media untuk hadir di kantor KPAI. Konferensi pers yang dilaksanakan di Kantor KPAI dihadiri oleh Komisioner KPAI, salah satunya di bidang Kesehatan dan Napza serta beberapa pihak internal KPAI lainnya. Mereka mengundang sejumlah media untuk meliput kegiatan konferensi pers. Pada 
konferensi pers tersebut pihak KPAl juga menjawab pertanyaan-pertanyaan yang diutarakan oleh media. Pembahasan yang diangkat adalah mengenai maksud awal KPAI yang bukan berniat untuk memberhentikan melainkan ingin logo dari Djarum tidak dipakai di tubuh anak yang mengikuti beasiswa mereka.

\section{Membuat Press Release}

Humas KPAI dalam menangani akibat yang timbul dari peristiwa tersebut mempersiapkan juga press release. Press release digunakan oleh Humas KPAI dengan tujuan untuk menyampaikan informasi dan juga pernyataan mengenai maksud dan niat dari KPAI, yakni hanya ingin PB Djarum tidak menggunakan brand image Djarum di dalam segala atribut yang dikenakan anak-anak peserta audisi bulu tangkis tersebut. Press release tersebut juga muncul di portal online serta televisi. Pada press release yang berjudul "Mendorong Audisi Badminton Ramah Anak" itu disampaikan tentang kajian yang sudah dilakukan beberapa stakeholder terkait dengan dampak iklan rokok pada anak, dan juga disampaikan mengenai Undang-Undang yang mengatur tentang iklan dan promosi yang berkaitan dengan bahan yang mengandung zat adiktif berupa produk tembakau.

Humas KPAI dan timnya menemukan hambatan, yaitu mencari rumusan cara penyampaian agar masyarakat mengerti maksud serta alasan KPAI pada peristiwa ini sehingga KPAI dapat menerima respons yang lebih baik dari masyarakat. Hal ini dianggap menjadi hambatan karena pihaknya merasa sudah mencoba menjelaskan dan memberi edukasi berkaitan dengan hal ini, tetapi yang dirasakan adalah masyarakat dapat dikatakan masih kurang memahami. KPAI pun merasakan efek yang besar khususnya pada reputasi KPAl yang dianggap menurun.

Dalam pelaksanaan strategi manajemen krisis yang dilakukan KPAI, pihaknya juga menyatakan bahwa mereka menerima dukungan dari beberapa pihak. dukungan tersebut berasal dari lembaga yang juga mengajukan pengaduannya ke KPAI. Lembaga yang mendukung KPAI di antaranya adalah Yayasan Lentera Anak (YLA) dan Yayasan Lembaga Konsumen Indonesia (YLKI). Bentuk dukungan yang diberikan ialah berupa pernyataan langsung dan ada pula yang konferensi pers. Lembaga tersebut setuju atas apa yang sudah dilakukan KPAI dan juga lembaga ini akan terus menegakkan yang ada dalam Peraturan Pemerintah mengenai iklan zat adiktif tersebut.

Public Relations memiliki tugas sebagai juru bicara ketika terjadi krisis, tetapi pada kenyataannya kasus yang baru saja terjadi pada KPAl yakni September 2019 yang menjadi juru bicara adalah top management yaitu Ketua KPAI dan Komisioner KPAI. Peranan Public Relations pada kasus ini ialah membantu mengambil tindakan yang akan dilakukan dan membantu merumuskan bentuk pernyataan yang akan disampaikan kepada publik. Tahapan manajemen krisis yang dilakukan oleh Public Relations KPAl adalah yang pertama melakukan rapat internal. Tindakan ini sejalan dengan tahap pertama pengelolaan krisis yang ditawarkan oleh Muray, yaitu melakukan briefing dengan tujuan memberikan informasi kepada pimpinan terkait dan memastikan setiap pihak internal yang terkait mendapat pengarahan ulang pada masalah sehingga setiap orang yang terlibat dapat tahu peranannya 
masing-masing ketika krisis terjadi.

Tahapan kedua adalah mempersiapkan konferensi pers. Konferensi pers merupakan sarana publikasi kepada masyarakat untuk menyampaikan pernyataan, mengumumkan atau menjelaskan suatu perihal. Tindakan ini sejalan dengan pengelolaan krisis yang ditawarkan Muray, yaitu mempersiapkan holding statement saat KPAl akan menyampaikan pernyataan terhadap masalah yang terjadi dan menghubungi media untuk hadir. Di sini KPAl juga melakukan komunikasi bertingkat secara cepat karena telah melakukan koordinasi antarpihak internal dan juga segera menyampaikan kepada media.

Tahapan ketiga adalah membuat press release. Tindakan ini sejalan dengan pengelolaan krisis yang ditawarkan Muray, yaitu mempersiapkan holding statement dan menggunakan strategi media yakni Public Relations KPAl mengirimkan press release-nya pada media terpilih, baik itu melalui daring maupun televisi.

Menurut Otto Lerbinger dalam Mazur \& White (1998), kategori krisis yang menimpa KPAl dikategorikan sebagai krisis konfrontasi. Krisis konfrontasi adalah krisis yang timbul karena gerakan massa melakukan proses dan kecaman terhadap korporasi. Ketika ada usaha perlawanan oleh individu atau suatu kelompok pada pemerintah dan/atau kepada berbagai kelompok yang berkepentingan untuk memenuhi tuntutan mereka. Hal itu dikategorikan sebagai krisis konfrontasi karena pada peristiwa ini KPAI menjalankan tugas lembaga sebagai fungsi pengawasan tetapi mendapat kecaman dari masyarakat untuk membubarkan lembaganya.

Teori Situasional Crisis Communication Theory (SCCT) atau teori komunikasi tentang krisis situasional. Teori ini menjelaskan tentang hubungan antara strategi respons krisis dengan situasi krisis yang digabungkan oleh organisasi untuk merangkai strategi respon krisis sebagai jawaban untuk menyelamatkan reputasinya (Coombs, 2004:266). Pada bagian itu telah diidentifikasi tiga jenis krisis berdasarkan tanggung jawabnya terhadap krisis. Yang pertama, yaitu korban (victim) memiliki tanggung jawab krisis yang lemah. Yang kedua adalah tidak disengaja (accidental), memiliki tanggung jawab krisis pada tingkat menengah karena dalam tipe krisis ini tindakan organisasi yang mengarah pada krisis ialah tanpa sengaja. Yang ketiga adalah dapat dicegah (preventable), pada tipe krisis ini organisasi dengan sengaja dan mengetahui bahwa mereka menempatkan orang pada risiko, mengambil tindakan yang tidak pantas atau melanggar hukum.

Sementara itu, terdapat tiga macam strategi respon krisis yang dilakukan sesuai dengan tanggung jawab krisisnya menurut Coombs (2007), antara lain yang pertama penyangkalan (denial) yakni pihak organisasi menyalahkan beberapa orang atau kelompok di luar organisasi untuk krisis. Kedua, meminimalisasi (diminish), yakni manajemen krisis untuk meminimalkan tanggung jawab organisasi. Ketiga, membangun kembali (rebuild), yakni pihak manajemen krisis menawarkan uang atau hadiah lain kepada korban sebagai bentuk tanggung jawab penuh atas krisis.

Sejalan dengan jenis krisis yang diidentifikasi oleh Coombs, yaitu jenis tidak disengaja (accidental). Jenis ini memiliki tanggung jawab krisis pada tingkat menengah 
karena dalam tipe krisis ini tindakan organisasi yang mengarah pada krisis ialah tanpa sengaja. Terjadinya krisis yang menimpa KPAI disebabkan oleh ketidaksengajaan atau tidak terkendali oleh organisasi karena peristiwa tersebut terjadi atas dasar pihaknya melakukan tugas pengawasan perlindungan anak yang bermula dari aduan yang muncul kepada KPAI. Dalam hal ini KPAl tergolong dalam ancaman reputasi sedang.

Tanggung jawab organisasi pada manajemen krisis dapat diantisipasi setelah mengetahui jenis krisis. Pesan yang disampaikan oleh KPAI melalui press release dan konferensi persnya adalah bahwa KPAl tidak bermaksud untuk memberhentikan audisi beasiswa tersebut, melainkan hanya ingin mengajukan untuk penggantian logo karena dianggap melanggar Undang-Undang pasal 37 terkait rokok dan Peraturan Pemerintah Nomor 109 tentang zat adiktif. Pihaknya pun menyampaikan kepada masyarakat bahwa mereka mendukung audisi bulu tangkis ramah anak. Retorika yang dibentuk dan disampaikan kepada publik oleh KPAI sejalan dengan strategi respon krisis yaitu meminimalisasi (diminish) yang berarti manajemen krisis untuk meminimalkan tanggung jawab organisasi dengan mengklaim bahwa pihaknya tidak ada niatan sama sekali untuk membuat audisi tersebut berhenti, hanya ingin di tubuh anak-anak peserta audisi tidak dijadikan bahan promosi berjalan.

\section{SIMPULAN}

Setelah melakukan penelitian tentang strategi manajemen krisis KPAl, peneliti menemukan Public Relations KPAI melakukan beberapa tahapan manajemen krisis, yakni melakukan rapat internal, melakukan konferensi pers, dan membuat press release. Mengacu pada Situasional Crisis Communication Theory (SCCT) atau teori komunikasi krisis, strategi yang dilakukan yaitu meminimalisasi (diminish), tim manajemen krisis meminimalkan tanggung jawab organisasi dengan mengklaim bahwa pihaknya tidak ada niat sama sekali untuk membuat audisi tersebut berhenti. Respons krisis KPAI pada saat krisis terjadi ialah memunculkan retorika yang disampaikan kepada publik, yakni pihaknya tidak bermaksud untuk memberhentikan audisi beasiswa tersebut dan menyampaikan kepada masyarakat bahwa mereka mendukung audisi bulu tangkis ramah anak.

Krisis yang menimpa KPAl digolongkan ke dalam jenis krisis yang disebut accidental (tidak disengaja). Terjadinya krisis yang menimpa KPAl itu disebabkan oleh ketidaksengajaan atau tidak terkendalinya situasi oleh organisasi karena peristiwa tersebut terjadi atas dasar pihaknya melakukan tugas pengawasan perlindungan anak yang bermula dari aduan yang muncul kepada KPAI. Public Relations KPAI telah berhasil mencocokkan strategi respons krisis dengan jenis krisis yang dihadapi. Artinya, penting sekali untuk mengenali tipe krisis yang dihadapi, dengan begitu kita tahu strategi yang akan diambil. Saat lembaga dihadapkan dengan krisis, kita juga memerlukan perencanaan yang baik sebelum menerapkan tahapan manajemen krisis. Hal ini bertujuan untuk menyelamatkan eksistensi lembaga dan membantu dalam pemulihan citra. 
Selain itu, hambatan yang dihadapi oleh Public Relations KPAI dalam melakukan strategi manajemen krisis adalah dibutuhkan suatu formula dalam menyampaikan informasi kepada masyarakat sehingga KPAI dapat menerima respons yang lebih baik dari masyarakat sehingga apa yang disampaikan dapat diterima pesannya dan agar tidak menambah masalah pada peristiwa ini. Adapun dukungan yang didapat saat pelaksanaan manajemen krisis dilakukan ialah dari Yayasan Lentera Anak dan Yayasan Lembaga Konsumen Indonesia. Bentuk dukungan yang diberikan ialah berupa pernyataan langsung dan ada pula yang melangsungkan konferensi pers. Lembaga tersebut setuju atas apa yang sudah dilakukan KPAI dan juga lembaga ini akan terus menegakkan yang ada dalam Peraturan Pemerintah mengenai iklan zat adiktif tersebut.

\section{DAFTAR RUJUKAN}

Ardianto, E dan Soemirat, S. (2004). Dasar-Dasar Public Relations. Bandung: PT Remaja Rosdakarya.

Bagong, S. (2005). Metode Penelitian Sosial. Jakarta: Kencana Prenada

Creswell, John W. (2008). Research Design, Pendekatan Kualitatif, Kuantitatif, dan Mixed. Bandung: Pustaka Pelajar

Nova, F. (2009). In Crisis Public Relations (Bagaimana PR menangani krisis). Jakarta: Raja Grafindo Persada.

Ruslan, R. (2006). Manajemen Public Relations dan Media Komunikasi, Konsepsi dan Aplikasi. Jakarta: Raja Grafindo Persada (2010). Manajemen Public Relations dan Media Komunikasi. Jakarta: Rajawali Pers

Adhiyasa, Donny. (2019, September 2012). Surat ini Jadi Bukti KPAI Ingin Audisi Bulutangkis Djarum Dihentikan. Vivanews.https://www.viva.co.id/sport/1233707surat-ini-jadi-bukti-kpai-ingin-audisi-bulutangkis-djarum-dihentikan 